\title{
ANALYSIS OF SOCIO-ECONOMIC FACTORS INFLUENCING FARMERS' ADOPTION OF IMPROVED MAIZE PRODUCTION PRACTICES IN IKARA LOCAL GOVERNMENT AREA OF KADUNA STATE, NIGERIA
}

\author{
${ }^{1}$ Issa, F. O. ${ }^{1} \mathrm{Kagbu}$, J. H. and ${ }^{2}$ Abdulkadir, S. A. \\ ${ }^{1}$ National Agricultural Extension and Research Liaison Services (NAERLS), \\ Ahmadu Bello University, Zaria, Nigeria. \\ 2Samaru College of Agriculture, Ahmadu Bello University, Zaria, Nigeria \\ Corresponding: issafola@gmail.com, issafola@abu.edu.ng, +2348033339312
}

\begin{abstract}
This study was conducted to analyze the socio-economic determinants of adoption of improved maize production practices (IMPPs) in Ikara Local Government Area of Kaduna State. Multi-stage sampling technique was employed to select 120 respondents for the study. The data were analyzed using frequency count, percentage, mean and inferential statistics (logit regression). Result of analysis revealed that most (42.5\%) of the farmers were between 25 and 34 years of age, male (94.2\%), married (58.3\%) and had secondary education (65.8\%). About 32\% of the farmers had between 20 and 29 years of farming experience. Majority (91.67\%) of the maize farmers had farm size of 1-3ha. Land preparation (97.5\%), manual weeding (89.2\%) and seed dressing (75.8\%) recorded the highest level of awareness among the IMPPs. Furthermore high cost of input (96.7\%), inadequate capital (95.0\%) and high cost of labour (88.3\%) were the major constraints to adoption of IMPPs. Farm size was found to be significantly related to adoption of IMPPs at $1 \%$ level of probability with positive coefficient (0.620). It was therefore recommended that extension should assist to form farmers into functional cooperatives, link them to available sources of credits so as to enable them take advantage of the available loan facilities.
\end{abstract}

Key words: Improved maize production practices, adoption, socio-economic, Kaduna State

\section{INTRODUCTION}

The Federal Ministry of Science and Technology (2004) reported that Nigeria has a wealth of improved maize varieties and management technologies that can double or triple traditional yields. Early maturing, drought and disease resistant, high yielding varieties of maize offer exciting new possibilities for multiple cropping in the future. The source of improved varieties are the National Seed Service, the relevant research institutes, state agricultural supply companies, seed companies and other agro-allied retailers. The seed produced by seed companies are treated with fungicides and pesticides and are certified by the National Seed Service.

Maize is used as a staple human food, as feed for livestock and as raw material for many industrial products (Abayomi et al., 2006). In many parts of the world, maize is the most important foodstuff and in particular provides the daily bread for indigenous population of poorer rural areas. Frova et al. (1999) asserted that maize is one of the world's three most important cereal crops (the others are rice and wheat) and it has the widest distribution of any cereal. According to them, the crop is primarily grown for its grain which is consumed as human foods. In some developed countries maize is also grown for animal feed and as a base for industrial products such as oil, syrup and starch.

Bencini (1991) also explained that the popularity of maize is due to its high yield, ease of transportation, protected by the husk against birds and rain, high storability if properly dried; wide cultivars with different maturity period and also ease of harvesting and dehusking without shattering. Fajemisin (1985) claimed that maize is a very important cereal crop in Nigeria. According to him, maize is usually consumed green during the longer periods immediately after the long dry season when tubers like yams and cassava and 
other food stuff becomes scarce. However, it is now known that because of the higher solar radiation received in the northern part of the country, relative to the southern part, the potential of maize production is greater in northern zones (NAERLS and FDAE 2015).

Improved agricultural practices are farming practices that have been researched on, tried and found to bring about increased crop yield (Ali-Olubandwa et al., 2010). The practices include use of certified seed, use of fertilizer and manure for planting and top-dressing, and correct use of pesticides for pest and diseases control among others. An estimated 5,622,000 metric tonnes of maize was produced between 2007 and 2014 in Kaduna State (NAERLS \& FDAE, 2014).

Kudi et al. (2010) explained that level of education, household size, farming experiences, access to credit and yield of improved maize varieties were found to be significantly related to the adoption of improved maize varieties. According to Komolafe et al. (2014), age, marital status, level of education and farming experiences were found to be significantly related to the adoption of improved crop practices. Marital status, educational level and household size of the maize farmers were found to be significant to the adoption of improved maize varieties (Umar et al., 2014). Idrisa et al. (2012) reported that education, yield, access to credit and extension contact were found to be significantly related to the adoption of improved maize seeds among farmers. Age, sex, level of education, farm size and extension contact were found to be significantly related to the adoption of improve maize production technology among farmers (Abdul-Rahman, 2013; Bawa and Ani, 2014). Jamilu et al. (2014) explained that age, educational level, extension contact and access to credit were found to be significantly related to the adoption of Sasakawa Global Maize Production Technologies among farmers. Olusegun et al. (2011) found that higher education level, farm size, as well as access to fertilizer and extension services would increase the probability of adopting improved maize varieties among maize farmers. Cotonou (1997) found that all farmers adopted fertilizer application in maize production while close spacing, required weeding and dig and cover method of fertilizer placement were rarely adopted by farmers.

Despite the popularity of maize in Ikara Local Government Area of Kaduna State, there is low productivity of this crop. This may be due to factors such as sowing of poor quality variety, late sowing, inaccurate sowing spacing, inappropriate fertilizer application timely and at right quantity, lack of use of chemicals to control pest and diseases, poor knowledge of appropriate moisture content of maize to be harvested and stored. Non-adoption of some farming practices such as dig and cover method of fertilizer placement, measurement of seed quantity to be planted and measurement of spacing between hill were considered too labour intensive and unnecessary (Cotonou, 1997). The major constraints to adoption were found to be lack of capital, high cost of fertilizer and lack of market for produce (Kudi et al., 2010). Moreover, nonadoption of improved maize production practices negatively affects maize production in the study area. Hence, the general objective of this study is to analyse the socio-economic factors influencing farmers' adoption of improved maize production practices (IMPPs) in Ikara Local Government Area of Kaduna State. The specific objectives are to:

i. describe the socio-economic characteristics of maize farmers;

ii. $\quad$ assess the level of awareness, and adoption of IMPPs;

iii. determine the factors influencing adoption of IMPPs, and

iv. examine the constraints to adoption of IMPPs in Ikara Local Government Area.

\section{METHODOLOGY}

\section{Study area}

Ikara Local Government is among the local government areas of Kaduna State. It was created in 1976, it has ten (10) wards. Ikara is located $30 \mathrm{~km}$ north-east of Zaria. The local government has total area of $1,641 \mathrm{~km}^{2}$ and is located between latitude 11002 " and $8^{\circ} 08$ and longitude $12^{\circ} 02^{\prime \prime} \mathrm{E}$. The neighboring local 
government that bordered Ikara are: Soba, Makarfi, Tudun-Wada, Kubau and Kiru Local Government. According to National Population Census (2006), Ikara had an estimated population of about 194, 723 people. With an annual growth rate of 3\%, Ikara Local Government has an estimated population of about 253, 140 people in 2016. The local government is dominated by Hausa and Fulani people whose major occupation is farming and livestock rearing. The local government has two distinct seasons, a long dry season (October -March/April) when agricultural activities is at a minimum and sufficient rainy season (April-September/October) when agricultural activities are at maximum (Bashir and Usman, 2008). People in the area are predominantly farmers, producing crops such as maize, rice, sorghum, millet, groundnuts, soyabeans, cassava, cowpea, pepper and tomatoes. The average annual rainfall is between 1,100-2,250mm. According to KADP (2014), there were approximately 2,153 maize farmers in Ikara Local Government Area. The approximate total number of maize farmers in each selected ward was: Auchan: 279; Kuya: 238; Rumi: 217 and Kurmin Kogi: 263.

\section{Sampling technique and sample size}

Multi-stage sampling technique was adopted to select sample for this study. The first stage involved the purposive selection of four (4) wards out of ten (10) wards in the local government. These wards are: Auchan, Kuya, Rumi and Kurmin-Kogi ward. Purposive selection was used to select wards based on high volume of maize production. The second stage involved random selection of two (2) villages under each ward selected. This gave a total of eight villages viz: Dogon-awo, Yar'gora, Kukoki, Anguwar-sarki, Wambai, Rafin-rogo, Nasarawa and Tashar-hasan. In the eight (8) villages selected, random selection of about $12 \%$ of the total number of maize farmers (997) was carried out to select the actual respondents for this study. Proportionate number of farmers was selected from each village because the number of maize farmers varies from one village to another. Hence, the total sample size for this study was 120.

\section{Data analysis}

Descriptive statistics such as frequency and percentage was used to analyze objectives i, ii, iii and v, while inferential statistics (logit regression) was used to analyze objective iv. The regression model is expressed as:

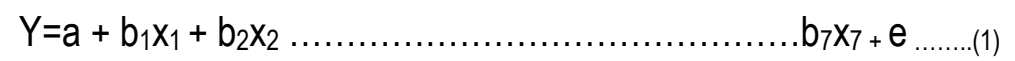

Where $Y=$ adoption of improved maize production practices (adoption $=1$, while non -adoption $=0$ )

$X_{1}=$ Age (years)

$X_{2}=$ Gender (male or female)

$X_{3}=$ Marital status (married, single, divorced, widowed)

$X_{4}=$ Educational status (years spent in school)

$X_{5}=$ Farming experience (years)

$X_{6}=$ Land acquisition (inheritance, purchase, lease, rent)

$X_{7}=$ Farm size $($ ha)

$a=$ Constant (intercept)

$\mathrm{e}=$ Error term

$b_{1}-b_{7}=$ regression parameters estimated

\section{RESULTS AND DISCUSSION}

\section{Socio-economic characteristics of maize farmers}

Result in Table 1 reveals that the mean age of farmers involved in maize farming was 40 years. This shows that the farmers were young and expected to have more energy to practice maize farming. This result is similar to the findings of Olaniyi and Adewale (2010), Idrisa et al. (2012), Jamilu et al. (2014) who found that maize farmers were between $30-35$ years. Similar to this finding, Onyedicachi (2015) found a mean age of 40.79 among rural farming household in Abia State, Nigeria. 
Most $(94.2 \%)$ of the farmers were male, while $5.8 \%$ were female. This indicates that male dominated maize farming in the study area. This finding is similar to that of Idrisa et al. (2012) where the percentage of male respondents was $87.7 \%$. More than half $(58.3 \%)$ of the maize farmers were married. This implies that married people concentrate on maize farming probably to provide food for their family members. This finding is similar to that of Umar et al. (2014) who found that majority of the farmers were married.

The majority $(65.8 \%)$ of the maize farmers had secondary school education. This shows that farmers possess the basic education to understand the implications of accepting IMPPs. This result negates the finding of Jamilu et al. (2014) who found low level of education among maize farmers. Majority (85\%) of maize farmers had 10 years of farming experience and above. This finding is similar to that of Komolafe et al. (2014) who found high farming experience among farmers. Also, majority (78.3\%) of the respondents owned their farm by inheritance. This indicates that land acquisition by inheritance is the most common way of acquiring farm in the study area. Inadequate capital might be responsible for this finding.

Most $(91.7 \%)$ of the farmers had between 1 and 3 hectares of land. This implies that maize farming is dominated by small scale farmers. This finding corroborates that of Jamilu et al. (2014) who found that maize farmers operate on small scale. Also, majority $(75.8 \%)$ of them used family labour exclusively. This implies that farmers in the area depend on themselves and their relatives/friends for acquiring farm labour that will assist them in their farming system. This finding agrees with the findings of Idrisa et al. (2012) that scarcity of labour was a major challenge for small scale farmers. 
Table 1: Distribution of maize farmers by socio-economic characteristics $(n=120)$

\begin{tabular}{|c|c|c|c|}
\hline Variables & Frequency & Percentage & Mean \\
\hline Age (years) & & & 32 \\
\hline $15-24$ & 16 & 13.3 & \\
\hline $25-34$ & 51 & 42.5 & \\
\hline $35-44$ & 27 & 22.5 & \\
\hline 45 and above & 26 & 21.7 & \\
\hline \multicolumn{4}{|l|}{ Sex } \\
\hline Male & 113 & 94.2 & \\
\hline Female & 7 & 5.8 & \\
\hline \multicolumn{4}{|l|}{ Marital status } \\
\hline Single & 47 & 39.2 & \\
\hline Married & 70 & 58.3 & \\
\hline Divorced & 3 & 2.5 & \\
\hline \multicolumn{4}{|l|}{ Education } \\
\hline No formal education & 27 & 22.5 & \\
\hline Primary & 14 & 11.7 & \\
\hline Secondary and above & 79 & 65.8 & \\
\hline Years of farming experience & & & 12 \\
\hline $1-9$ & 18 & 15 & \\
\hline $10-19$ & 36 & 30 & \\
\hline $20-29$ & 38 & 31.7 & \\
\hline 30 and above & 28 & 23.3 & \\
\hline \multicolumn{4}{|l|}{ Method of land acquisition } \\
\hline Rent & 9 & 7.5 & \\
\hline Lease & 4 & 3.3 & \\
\hline Inheritance & 94 & 78.3 & \\
\hline Purchase & 13 & 10.8 & \\
\hline Farm Size (ha) & & & 2 \\
\hline $1-3$ & 110 & 91.67 & \\
\hline $4-6$ & 7 & 5.83 & \\
\hline $7-9$ & 1 & 0.83 & \\
\hline 10 and above & 3 & 2.5 & \\
\hline \multicolumn{4}{|l|}{ Sources of Labour* } \\
\hline Family & 91 & 75.8 & \\
\hline Hired & 52 & 43.3 & \\
\hline Cooperative & 48 & 40 & \\
\hline All of the above & 31 & 25.8 & \\
\hline \multicolumn{4}{|l|}{ Sources of capital ${ }^{*}$} \\
\hline Banks & 30 & 25 & \\
\hline Friends/relatives & 79 & 65.8 & \\
\hline Government grant & 30 & 25 & \\
\hline Re-invested profit & 76 & 63.3 & \\
\hline
\end{tabular}

${ }^{*}$ Multiple responses

\section{Level of farmers' awareness of IMPPs}

Result in Table 2 shows that farmers had high level of awareness in land preparation techniques (97.5\%), use of manure $(89.2 \%)$ and seed dressing $(75.8 \%)$. This implies that maize farmers were familiar with 
these practices. This finding is similar to the finding of Cotonou (1997) which showed that land preparation and use of manure recorded high awareness by farmers.

The extent of awareness and adoption of new maize varieties by maize farmers was high (Kudi et al., 2011); they further explained that maize farmers found information on improved maize varieties from radio, extension agents, other farmers, village/ward heads and their friends while explaining that most of the farmers obtained information (awareness) through extension agents. Majority of the farmers obtained information from extension agents followed by fellow farmers (Komolafe et al., 2014). Jamilu et al. (2014) explained that maize farmers who adopted the technologies benefited a lot from increased awareness, yield, and income. Radio, fellow young farmers, extension agents, cooperative societies, commercial input dealers and parents were the major sources of information among farmers (Olaniyi and Adewale, 2012). Cotonou (1997) reported that all maize farmers had full awareness about the need for fertilizer application in maize production; while most of them (54.5\%) had correct knowledge of required weeding; while appropriate planting technique is rarely known (36\%).

Table 2: Distribution of maize farmers by level of awareness of IMPPs

\begin{tabular}{llll}
\hline IMPPs & Aware & Not aware & Rank \\
\hline Appropriate land preparation & $117(97.5)$ & $3(2.5)$ & $1^{\text {st }}$ \\
Use of manure & $107(89.2)$ & $13(10.8)$ & $2^{\text {nd }}$ \\
Seed dressing & $91(75.8)$ & $29(24.2)$ & $3^{\text {rd }}$ \\
Appropriate planting techniques & $82(68.3)$ & $38(31.7)$ & $4^{\text {th }}$ \\
Appropriate harvesting & $81(67.5)$ & $39(32.5$ & $5^{\text {th }}$ \\
Use of herbicides & $79(65.8)$ & $41(34.2)$ & $6^{\text {th }}$ \\
Use of fertilizer & $75(62.5)$ & $45(37.5)$ & $7^{\text {th }}$ \\
Use of improved seed & $55(45.8)$ & $65(54.2)$ & $8^{\text {th }}$ \\
\hline
\end{tabular}

Percentages are in parentheses

\section{Major Sources of Information}

Table 3 shows that radio was the major source of information for majority $(92.5 \%)$ of the farmers in the study area. This indicates that radio serves a major avenue for the dissemination of information to farmers. This finding is contrary to the reports of Idrisa et al. (2012) that radio was less important for spreading of information to farmers.

Table 3: Distribution of farmers based on their sources of information on IMPPs

\begin{tabular}{llll}
\hline Sources of Information on IMPPs & Used & Not used & Rank \\
\hline Radio & $111(92.5)$ & $9(7.5)$ & $1^{\text {st }}$ \\
Relatives/friends & $110(91.7)$ & $10(8.3)$ & $2^{\text {nd }}$ \\
Fellow farmers & $105(87.5)$ & $15(12.5)$ & $3^{\text {rd }}$ \\
Non-Governmental Organizations & $64(53.3)$ & $56(46.7)$ & $4^{\text {th }}$ \\
ADP Extension agents & $46(38.3)$ & $74(61.7)$ & $5^{\text {th }}$ \\
Research institutes & $38(31.7)$ & $82(68.3)$ & $6^{\text {th }}$ \\
Television & $32(26.7)$ & $88(73.3)$ & $7^{\text {th }}$ \\
Field day & $25(20.8)$ & $95(79.2)$ & $8^{\text {th }}$ \\
\hline
\end{tabular}

Percentages are in parentheses 


\section{Level of Farmers' adoption of IMPPs}

Table 4 shows the distribution of respondents based on their level of adoption of IMPPs. Appropriate land preparation, use of manure and seed dressing were the most adopted practices among farmers. This result indicates that maize farmers found those practices easy to adopt. The most commonly and highly adopted practices was land preparation such as ploughing, harrowing and ridging, with the highest percentage of respondents (85\%). According to Cotonou (1997), the farmers who adopted ridging as a method of land preparation had a low percentage (38.3\%).

Table 4: Distribution of farmers by their level of adoption of IMPPs

\begin{tabular}{lllll}
\hline IMPPs & Highly used & Moderately used & Low used & Not used \\
\hline Use of improved seeds & $19(15.8)$ & $18(15.0)$ & $13(10.8)$ & $70(58.3)$ \\
Appropriate land preparation & $102(85.0)$ & $7(5.8)$ & $5(4.2)$ & $6(5)$ \\
Appropriate Planting time & $52(43.3)$ & $14(11.7)$ & $10(8.3)$ & $44(36.7)$ \\
Use of seed dressing & $42(35.0)$ & $32(26.7)$ & $19(15.8)$ & $27(22.5)$ \\
Use of fertilizer & $33(27.5)$ & $26(21.7)$ & $24(20.0)$ & $37(30.8)$ \\
Use of pesticides & $48(40.0)$ & $13(10.8)$ & $12(10)$ & $47(39.2)$ \\
Use of manure & $64(53.3)$ & $16(13.3)$ & $11(9.2)$ & $29(24.2)$ \\
Appropriate Harvesting technique & $52(43.3)$ & $16(13.3)$ & $14(11.7)$ & $38(31.7)$ \\
\hline
\end{tabular}

Percentages are in parentheses

\section{Socio-economic Factors influencing adoption of IMPPs}

The result of logit regression analysis in Table 5 shows that only farm size had positive and significant relationship with adoption of IMPPs with positive coefficient of $(0.620)$ at $1 \%$ level of probability. This implies that the larger the farm size, the higher the adoption of improved maize production practices. This finding negates the findings of Idris et al. (2012) that farm size had nothing to do with adoption. Similar to the findings of this study, Bawa and Ani (2014) and Olusegun et al. (2014) reported that farm size had bearing on the capacity of farmers to utilize agricultural innovation and new farm practices. They indicated that there was positive and significant relationship between farm size and agricultural innovation utilization.

Contrary to apriori expectation, age was not significant to adoption of IMPPs. However, Abdul-Rahman (2013) and Komolafe et al. (2014) found that as farmers become older, their productivity will decline. Komolafe et al. (2014) also found that farmers with high level of education adopt new technologies easily and use them effectively while farmers with more years of farming experiences will be more efficient in farm production. However, findings in this study show that adoption of IMPPs is irrespective of level of education and farming experience. 
Table 5: Logit regression analysis on socio-economic factors influencing adoption of IMPPs

\begin{tabular}{llllll}
\hline Variables & B & $\begin{array}{l}\text { Standard } \\
\text { error }\end{array}$ & Beta & T & sig \\
\hline Constant & 99.393 & 11.925 & & 8.335 & 0.000 \\
Age & -1.395 & 1.710 & -110 & -.816 & 0.416 \\
Gender & -3.333 & 5.856 & -.054 & -.569 & 0.570 \\
Marital status & 1.762 & 2.837 & .065 & .621 & 0.536 \\
Educational status & 1.88 & 1.541 & .078 & .771 & 0.442 \\
Farming experiences & -.078 & .170 & -.060 & -.457 & 0.648 \\
Land acquisition & -3.387 & 2.054 & -.155 & -1.649 & 0.102 \\
Farm size & .620 & .230 & .255 & 2.696 & $0.008^{*}$ \\
\hline
\end{tabular}

Pseudo $r$-square $=0.19$

*Significant at $1 \%$ level of probability

\section{Constraints to adoption of IMPPs}

The constraints to adoption of IMPPs are presented in Table 6. The Table shows that the most common constraints to adoption of IMPPs were high cost of inputs (96.7\%), inadequate capital (95.0\%), and high cost of labour (88.3\%). This finding is similar to the findings of Kudi et al. (2010) that major constraints to adoption was lack of capital and high cost of inputs. However, Umar et al. (2014) found that unavailability of seed was the major constraint of maize production to maize farmers, followed by inadequate fertilizer. Cotonou (1997) reported that high cost of labour was responsible for non-adoption of recommended practices such as dig-and-cover method of fertilizer placement, measurement of seed quantity to be planted and measurement of spacing between hills.

Table 6: Distribution of farmers based on constraints to adoption of IMPPs

\begin{tabular}{llll}
\hline Constraints & Major & Not major & Ranking \\
\hline High cost inputs & $116(96.7)$ & $4(3.3)$ & $1^{\text {st }}$ \\
Inadequate capital & $114(95.0)$ & $6(5.0)$ & $2^{\text {nd }}$ \\
High cost of labour & $106(88.3)$ & $14(11.7)$ & $3^{\text {rd }}$ \\
Inadequate technical know-how & $96(80.0)$ & $24(20.0)$ & $4^{\text {th }}$ \\
Non profitability of maize farming & $85(70.8)$ & $35(29.2)$ & $5^{\text {th }}$ \\
Bad weather & $77(64.2)$ & $43(35.8)$ & $6^{\text {th }}$ \\
Unavailability of land & $68(56.7)$ & $52(43.3)$ & $7^{\text {th }}$ \\
Prevalence of pests and diseases & $42(35.0)$ & $78(65.0)$ & $8^{\text {th }}$ \\
Poor soil fertility & $40(33.3)$ & $80(66.7)$ & $9^{\text {th }}$ \\
Low maize yield & $38(31.7)$ & $82(68.3)$ & $1^{\text {th }}$ \\
\hline
\end{tabular}

Percentages are in parentheses

\section{Conclusion and Recommendations}

This study has established that farmers had high level of awareness in land preparation techniques, use of manure and seed dressing. Radio was the most important source of information for majority of the farmers. The most adopted production practices among farmers include appropriate land preparation, use of manure and seed dressing. Also, the major constraints to adoption of IMPPs were high cost of inputs, inadequate capital, and high cost of labour. This study also concludes that age, gender, marital status, educational level, farming experience, land acquisition, neither promote nor encourage adoption of IMPPs.

Based on these findings, the following recommendations are made: 
i. Extension workers should assist farmers to form viable and functional cooperatives. This will enable them pool their resources together as well as create opportunities to access loans which can be used to enhance their production capacity.

ii. High cost of inputs was a major constraint in maize farming. Therefore, government should provide relevant inputs (seed, fertilizer and agrochemicals) at subsidize price affordable by farmers.

\section{References}

Abayomi, Y. A., Arijenja-George, A. and Kolawole, I. A. (2006). Comparative leaf growth and grain yield response of hybrid and open pollinated maize genotype to nitrogen fertilizer application. Agrosearch, 8:13-25.

Abdul-Rahman, S. (2013). Farm production efficiency. The scale of success in agriculture, Nasarawa State University. Keffi, Nigeria.

Ali-Olubandwa, A. M., Odero-Wanga, D., Kathuri, N. J. and Shivoga, W. A. (2010). Adoption of improved maize production practices among small scale farmers in the agricultural reform era: The case of Western Province of Kenya. Journal of International Agricultural and Extension Education, 17(1): $21-30$.

Bashir, M. and Usman, A. (2008). Socio-economic factors influencing farmers' adoption of improved maize varieties in Ikara Local Government Area of Kaduna State. Unpublished HND Agricultural Extension and Management Thesis, Samaru College of Agriculture, ABU, Zaria.

Bawa, D.B. and Ani, A.O. (2014). Analysis of Adoption of Improved maize production technologies among farmers in Southern Borno, Nigeria. Research on Humanities and Social Science 4(255): 43 54.

Bencini, M.C. (1991). Post-harvest and processing technology, Food Agricultural Organization of the United Nations.

Cotonou, I. (1997). Strategy for sustainable maize production in West and Central Africa. Proceedings of a regional maize workshop. Edited by B. Badu-Apraku, M.A.B. Fakorede, M. Ouedraogo and F.M. Quin, published by West Central and African Collaborative Maize Research Network (WECAMAN).

Fajemisin, B. O. (1985). Status of maize production technology in Nigeria and prospects of sustained self-sufficiency. A paper presented at the NASPP third work at Oweri, Nigeria.

Federal Ministry of Science and Technology (2004). Report on survey of selected agricultural raw materials in Nigeria on maize. Raw Materials Research and Development Council, Federal Ministry of Science and Technology, Garki, Abuja.

Frova, C., Krajewski, P., Fonzo, N. D., Villa, M. and Sari-Gorla, M. (1999). Genetic Analysis of DroughtTolerance maize by molecular markers. Theory and Applied Genetics. 99: 280 - 288.

Idrisa, Y.L.; Shehu, H. and Ngamdu, M.B. (2012). Effect of Adoption of improved maize seed on household food security in Gwoza Local Government Area of Borno State Nigeria. Global Journal, volume 12, ISSN 5 version.

Jamilu, A.A.; Abdul-Aziz, H.; A.K. Jafaru; B.M. Sani and Abudu, S. (2014). Factors influencing the adoption of Sasakawa Global 2000 maize production technologies among small holder farmers in Kaduna State. Journal of Agricultural Extension 18(1): 73-83.

Kaduna State Agricultural Development Project (2014). Information on maize farmers, Ikara L.G.A.

Komolafe, S. E., Adeseji, G. B. and Ajibola, B.O. (2014). Determinant of adoption of improved crop practices among women farmers in Ekiti East L.G.A. of Ekiti, Nigeria. Journal of Agricultural Research, 5(2): 22-31.

Kudi, T.M.; Bolaji, M.; Akinola, M.O. and Nasa, I.O.H. (2010). Analysis of adoption of improved maize varieties among farmers in Kwara State, Nigeria. International Journal of Peace and Development Studies, 1(3): 8-12.

National Agricultural Extension and Research Liaison Services (NAERLS) and Federal Department of Agricultural Extension (FDAE) (2014). Agricultural performance survey of 2014 wet season in Nigeria, Executive summary. October. Pp 23. 
National Agricultural Extension and Research Liaison Services (NAERLS) and Federal Department of Agricultural Extension (FDAE) (2015). Agricultural performance survey report of 2015 wet season in Nigeria, NAERLS Press, Ahmadu Bello University, Zaria. Pp 181.

National Population Census (2006). Information of National Statistic, National Population Commission, Nigeria.

Olaniyi, O.A. and Adewale, J.G. (2012). Information on maize production among rural youths. A solution for sustainable food security in Nigeria.

Olusegun, A. F., Dare, A. and Begh, T. (2011). Factors influencing adoption decisions of maize farmers in Nigeria. International Journal of Food and Agricultural Economics. 2(3): 45-54.

Onyedicachi, A. C. (2015). The effect of social capital on access to micro credit among rural farming households in Abia State, Nigeria. Agrosearch 15(1): 59 - 75. Available @ Http://Dx.Doi.Org/10.4314/Agrosh.V15i1.4. Retrieved $7^{\text {th }}$ March, 2016.

Umar, S.; Musa, M.W. and Kamsang, L. (2014). Determinant of adoption of improve maize varieties among resource poor household in Kano and Katsina State, Nigeria. Journal of Agricultural Extension. 18(2): 115-124. 